\title{
Limites de movimentos mandibulares em crianças*****
}

\author{
Mandibular movement range in children
}

\author{
Barbara Cristina Zanandréa Machado* \\ Ana Paula Magalhães Medeiros** \\ Cláudia Maria de Felício***
}

*Fonoaudióloga. Aperfeiçoamento em Interação Ortodontia e Fonoaudiologia promovido pela Faculdade de

Odontologia de Ribeirão Preto da Universidade de São Paulo (USP).

Monitora do Curso de Aperfeiçoamento em Motricidade Oral do Departamento de Clínica Infantil, Odontologia Preventiva e Social da Faculdade de Odontologia de Ribeirão Preto - USP. Endereço para correspondência: Rua Gonçalves de Magalhães, 388 -

Ribeirão Preto - SP - CEP 14030-570 (babiusp@yahoo.com.br).

**Fonoaudióloga. Pós-Graduada do Departamento de Oftalmologia, Otorrinolaringologia e Cirurgia de Cabeça e Pescoço da Faculdade de Medicina de Ribeirão Preto da USP. Monitora do Curso de Aperfeiçoamento Interação Ortodontia e Fonoaudiologia - Faculdade de Odontologia de Ribeirão Preto - USP.

*** Fonoaudióloga. Doutora em Ciências pela USP. Professora do Departamento de Oftalmologia, Otorrinolaringologia e Cirurgia de Cabeça e Pescoço - Área

Fonoaudiologia da Faculdade de Medicina de Ribeirão Preto da USP.

****Trabalho Realizado na Faculdade de Medicina de Ribeirão Preto da USP.

Artigo Original de Pesquisa

Artigo Submetido a Avaliação por Pares

Conflito de Interesse: não

\section{Abstract}

Background: identification of the mandibular movement range is an important procedure in the evaluation of the stomatognathic system. However, there are few studies in children that focus on normal parameters or abnormalities. Aim: to determine the average range of mandibular movements in Brazilian children aged 6 to 12 years; to verify the difference between genders, in each age group, and between the different age groups: 6-8 years; 8.1-10 years; and 10.1-12 years. Method: participants of the study were 240 healthy children selected among regular students from local schools of São Paulo State. The maximum mandibular opening, lateral excursion and protrusive movements, and deviation of the medium line, if present, were measured using a digital caliper. Student T test, Analysis of variance and Tukey test were considered significant for $\mathrm{p}<0.05$. Results: the mean values observed in the studied sample were: $44.51 \mathrm{~mm}$ for maximum mandibular opening; $7.71 \mathrm{~mm}$ for lateral excursion to the right; $7.92 \mathrm{~mm}$ for lateral excursion to the left; $7.45 \mathrm{~mm}$ for protrusive movements. No statistical difference was observed between genders. There was a gradual increase in the range of mandibular movements, with significant differences mainly between the ages of 6-8 years and 10.1-12 years. Conclusion: during childhood the range of mandibular movements increases. Age should be considered in this analysis for a greater precision in the diagnosis.

Key Words: Stomatognathic System; Range of Motion; Child; Diagnosis.

\section{Resumo}

Tema: a determinação dos limites de movimentos mandibulares é um importante procedimento na avaliação do estado funcional do sistema estomatognático, porém poucos são os estudos que focalizam os parâmetros de normalidade ou desvios em crianças. Objetivos: definir as médias dos limites de movimentos mandibulares em crianças brasileiras de 6 a 12 anos de idade; verificar diferenças entre os gêneros, em cada faixa etária, e entre as faixas etária de 6 a 8 anos, 8:1 a 10 anos e 10:1 a 12 anos de idade. Método: participaram 240 crianças, escolares do interior do Estado de São Paulo. Com o auxílio de um paquímetro digital foram mensuradas a máxima abertura mandibular, a protrusão, a excursão lateral direita e esquerda e o desvio da linha média, quando presente. O teste T Student, a Análise de variância e o pós-teste Tukey foram considerados significantes para $\mathrm{p}<0,05$. Resultados: as médias das medidas da amostra foram: máxima abertura mandibular $44,51 \mathrm{~mm}$, excursão lateral direita $7,71 \mathrm{~mm}$, excursão lateral esquerda 7,92 mm e a protrusão $7,45 \mathrm{~mm}$. Não houve diferença estatística entre os gêneros. Houve aumento gradual nos limites dos movimentos mandibulares com o aumento da faixa etária, com diferenças significantes principalmente entre as faixas etárias de 6 - 8 anos e 10:1-12 anos. Conclusão: durante a infância os limites de movimentos mandibulares aumentam e a idade deve ser considerada na análise desses dados para maior precisão no diagnóstico.

Palavras-Chave: Sistema Estomatognático; Amplitude de Movimento Articular; Criança; Diagnóstico. 


\section{Introduction}

In the assessment of the functional status of the stomatognathic system the determination of the mandibular movement range is an important procedure (1) since reduced movements have been considered to be clinical signs in the diagnosis of problems affecting or related to the orofacial system, among them temporomandibular disorders (TMD) (2-6) and neurogenic disorders (7).

There is a great demand for clinical speech therapy for children aged six to 12 years, but normal data regarding maximum mandibular opening, lateral excursion and protrusion in children are scarce both in the international $(3,8-10)$ and in the Brazilian $(1,6,11)$ literature.

In addition, there is controversy about the relationship between mandibular range of movements and the following variables: gender, age, body height, facial morphology, gonial angle, mandibular ramus length, angle of mouth opening, neuromotor development, and circulatory disorders $(3,9,11-20)$.

The objectives of the present study were to define the mean mandibular range of movements of Brazilian children aged 6 to 12 years, to determine gender differences in each age range and differences between the 6-8, 8.1-10 and 10.1-12 year ranges in order to define normality parameters.

\section{Method}

The study was approved by the Human Research Ethics Committee of the University Hospital, Faculty of Medicine of Ribeirão Preto, University of São Paulo (HCFMRP-USP), Process HCRP n ${ }^{\circ} 89 / 2007$, and all persons responsible for the children gave written informed consent to participate in the study.

\section{Subjects}

A total of 240 children aged 6 to 12 years from municipal schools participated in the study. Children presenting signs and symptoms of TMD, a history of facial trauma and of head and neck surgery, children wearing braces, children with neurological disorders and craniofacial deformities or systemic diseases were excluded from the study.

Subjects were selected using the validated protocol for multiprofessional centers for the determination of signs and symptoms of TMD (ProTMDmulti) (21) (enclosed), which permits to differentiate between asymptomatic and TMD subjects (22). The protocol was complemented with information provided by the child, the family and school staff, and with observation during the evaluation of mandibular movements.

The sample was divided into three groups according to age range, as follows:

- Group I (6 to 8 years of age) consisting of 89 children, 44 girls and 45 boys;

- Group II (8.1 to 12 years) consisting of 79 children, 38 girls and 41 boys, and

- Group III (10.1 to 12 years of age) consisting of 72 children, 45 girls and 27 boys.

The sample was also subdivided into gender: male (M) and female (F).

Procedure

A history was taken with the children and the persons responsible for them in order to obtain the information needed for the study, such as identification, age, developmental data, health, and signs and symptoms of TMD.

During the session for evaluation, the subjects sat in a chair with a back support, with their feet resting on the floor. With the aid of a digital Mitutoyo pachymeter - Series 500 - Absolute Coolant Proof IP66, with 0.01 repeatability and $\pm 0.02 \mathrm{~mm}$ accuracy, positioned on point zero at each new measurement, mandibular movements were measured as follows:

- maximum mandibular opening: the distance between the incisal ridge of the upper and lower incisors was considered during maximum mouth opening up to the painless limit, plus the measurement of vertical overbite;

- protrusion: with the teeth in occlusion, the distance from the vestibular surface of the lower incisors to the incisal ridge of the upper incisors was measured. The subject was then asked to protrude his mandible by sliding it along the maxilla and the horizontal distance from the vestibular surface of the upper incisors to the incisal ridge of the lower incisors was measured. The sum resulted in the measure of mandibular protrusion;

- laterality: the subject was asked to perform maximum dislocation of the mandible to the right and the horizontal distance between the line that passes through the upper central incisors and the lower central incisors or between the lip frena was measured. The same procedure was used to measure left lateral excursion (23).

The measurements were made by a previously trained examiner with 0.98 test-retest reliability determined in a previous study. A second examiner 
re-evaluated $20 \%$ of the subjects selected at random. According to the split-half test, interexaminer reliability was high (0.91) and correlation was 0.83 .

Data analysis

Data were analyzed by descriptive statistics for the definition of the means, standard deviations and confidence limits regarding the mandibular range of movements. The parametric test one-way ANOVAwas used to analyze the gender and age range variables, followed by the Tukey post-test to determine differences between groups. The level of significance was set at 0.05 in all analyses.

\section{Results}

The mean measures for the sample as a whole were: maximum mandibular opening, $44.51 \mathrm{~mm}$; right lateral excursion; $7.71 \mathrm{~mm}$, left lateral excursion, 7.92 $\mathrm{mm}$, and protrusion, $7.45 \mathrm{~mm}$.

There was no significant difference between males and females ( $p>0.05)$ for the same age range. The mean values, standard deviations and confidence intervals of the measures (in $\mathrm{mm}$ ) according to age range and gender are given in Table 1.

Considering the lack of difference between genders, the groups were compared according to age range. There was a significant difference in the measures of maximum mandibular opening and protrusion between Groups I, II and III, with the mean for Group II being higher than the mean for Group I and lower than the mean for Group III. The measure of right lateral excursion was significantly lower for Group I compared to Group III ( $\mathrm{p}<0.05$ ). The mean values, standard deviations and confidence intervals of the measures (in $\mathrm{mm}$ ) according to age range and to the results of group comparisons are given in Table 2.

TABLE 1. Means, standard deviation and confidence interval according to age and gender.

\begin{tabular}{|c|c|c|c|c|c|c|}
\hline Groups & & Age & MMO & RLE & LLE & $\mathrm{Pt}$ \\
\hline \multirow[t]{2}{*}{$\mathrm{IF}$} & Mean \pm SD & $6.59 \pm 0.50$ & $42.56 \pm 5.8$ & $7.13 \pm 2.84$ & $7.79 \pm 2.51$ & $6.33 \pm 2.56$ \\
\hline & $95 \% \mathrm{CI}$ & & $40.8-48.3$ & $6.3-8.0$ & $7.0-8.6$ & $5.6-7.1$ \\
\hline \multirow[t]{2}{*}{$\mathrm{IM}$} & Mean \pm SD & $6.58 \pm 0.50$ & $40.83 \pm 6.30$ & $7.23 \pm 2.70$ & $7.61 \pm 2.69$ & $6.40 \pm 2.58$ \\
\hline & $95 \%$ CI & & $38.9-42.7$ & $6.4-8.0$ & 6.8-8.4 & $5.6-7.2$ \\
\hline \multirow[t]{2}{*}{$\mathrm{IIF}$} & Mean \pm SD & $8.61 \pm 0.50$ & $45.12 \pm 5.83$ & $6.98+2.39$ & $7.94 \pm 2.56$ & $7.23 \pm 2.04$ \\
\hline & $95 \%$ CI & & $43.2-47.0$ & $6.2-7.8$ & $7.1-8.8$ & $6.6-7.9$ \\
\hline \multirow[t]{2}{*}{ IIM } & Mean \pm SD & $8.59 \pm 0.50$ & $45.18 \pm 4.69$ & $8.55 \pm 2.17$ & $8.31 \pm 2.5$ & $7.99 \pm 1.89$ \\
\hline & $95 \% \mathrm{CI}$ & & $43.7-46.7$ & $7.9-9.2$ & $7.5-9.1$ & $7.4-8.6$ \\
\hline \multirow[t]{2}{*}{ IIIF } & Mean \pm SD & $11.33 \pm 0.80$ & $47.31 \pm 5.82$ & $8.02 \pm 1.94$ & $8.28 \pm 2.75$ & $8.63 \pm 1.54$ \\
\hline & $95 \% \mathrm{CI}$ & & $45.6-49.1$ & $7.4-8.6$ & $7.5-9.1$ & $8.2-9.1$ \\
\hline \multirow[t]{2}{*}{ IIIM } & Mean \pm SD & $10.93 \pm 0.92$ & $47.62 \pm 6.41$ & $8.80 \pm 2.49$ & $7.47 \pm 3.34$ & $8.54 \pm 2.06$ \\
\hline & $95 \% \mathrm{CI}$ & & $45.1-50.2$ & $7.8-9.8$ & 6.1-8.8 & 7.7-9.4 \\
\hline$P$ value & & & 0.000 & 0.003 & 0.683 & 0.000 \\
\hline
\end{tabular}

F: female, M: male, MMO: maximum mandibular opening, RLE: right lateral excursion, LLE: left lateral excursion, Pt: protrusion. ANOVA with one variation factor.

TABLE 2. Means, standard deviations, and confidence intervals according to age and group comparison.

\begin{tabular}{|c|c|c|c|c|c|c|}
\hline Groups & & Age & MMO & RLE & LLE & $\overline{\mathrm{Pt}}$ \\
\hline \multirow[t]{2}{*}{$\mathrm{I}$} & Mean \pm SD & $6.58 \pm 0.50$ & $41.69^{a} \pm 6.09$ & $7.18^{\mathrm{a}} \pm 2.76$ & $7.70^{\mathrm{a}} \pm 2.59$ & $6.37^{\mathrm{a}} \pm 2.56$ \\
\hline & $95 \% \mathrm{CI}$ & ---------- & $40.4-43.0$ & 6.6-7.8 & 7.2-8.2 & $5.8-6.9$ \\
\hline \multirow[t]{2}{*}{ II } & Mean \pm SD & $8.59 \pm 0.49$ & $45.15^{\mathrm{b}} \pm 5.23$ & $7.79^{a . b} \pm 2.39$ & $8.13^{a} \pm 2.52$ & $7.63^{b} \pm 1.99$ \\
\hline & $95 \% \mathrm{CI}$ & ---------- & $44.0-46.3$ & 7.3-8.3 & 7.6-8.7 & 7.2-8.1 \\
\hline \multirow[t]{2}{*}{ III } & Mean \pm SD & $11.18 \pm 0.86$ & $47.43^{c} \pm 6.01$ & $8.31^{b} \pm 2.18$ & $7.98^{\mathrm{a}} \pm 2.98$ & $8.60^{c} \pm 1.74$ \\
\hline & $95 \% \mathrm{CI}$ & ---------- & $46.0-48.8$ & $7.8-8.8$ & 7.3-8.7 & $8.2-9.0$ \\
\hline valor de $P$ & & 0.0000 & 0.0000 & 0.016 & 0.57 & 0.0000 \\
\hline
\end{tabular}

MMO: maximum mandibular opening, RLE: right lateral excursion, LLE: left lateral excursion, Pt: protrusion. ANOVA with one variation factor. Means followed by different superscript letters $(a, b, c)$ differed significantly by the Tukey test $(P<0.05)$. 


\section{Discussion}

The determination of the means and standard deviations of the mandibular range of movement according to age and gender is justified by the need for parameters for the diagnosis of disorders involving the functionality of the stomatognathic system. Thus, the objective of the present study was to determine the measures of maximum mandibular opening, right and left mandibular excursion and protrusion in Brazilian children aged 6 to 12 years according to age range and gender, as well as to compare the measures of the groups divided into three age ranges.

No significant difference was observed between genders regarding the measure of excursive mandibular movements, in agreement with previous studies $(3,6,8,24)$. The measures studied seem to follow the same tendency of other physical characteristics that start to differentiate according to gender at puberty since gender differences have been detected in samples of adolescents and adults $(2,10,15,19,20)$.

Greater amplitude of maximum mandibular opening, right lateral excursion and protrusion was observed with increasing age range, corroborating previous findings (1,3,8-11). Significant differences in the measures of left lateral excursion and protrusion were observed in a recent study on Brazilian children aged 7-10 and 12-14 years (6).

The measures obtained in the present study were higher than the means obtained for children aged 1 to 1 and a half years (8) and only the lowest age range presented means close to those of children aged 3 to 5 years (24).

Compared to the measurements obtained for children of the same age ranges, the present results agreed with some studies $(6,8)$, but in general were inferior to other results $(3,11)$. Characteristics of the children such as weight an height may perhaps explain the differences in results, but only Vanderas(3) considered height, which was positively correlated with the extension of mandibular movements. Also, the instrument used in the present study, which was digital and of high precision, may have contributed to some differences.
The increased mandibular range of movement with increasing age ranges $(3,6,8,11,24)$ may be related to anatomical changes, to the maturation of the central nervous system, to skeletal growth and to the maturation of occlusal function and of oral motor control (25-30).

Clinical evaluation should be based on a very thorough foundation and therefore normative data should be investigated in different populations. The measurement of the mandibular range of movements provided reliable quantitative data as shown by the intra- and inter-examiner reliability and also by the agreement of the present data with previously published ones.

Thus, these measures may be valid for the diagnosis and clinical control of patients with orofacial myofunctional disorders and/or TMD, and as the measurement of the result of myofunctional therapy aiming at the liberty, symmetry and control of mandibular movements.

\section{Conclusion}

The present study permitted us to conclude that:

- The mean measures of the range of mandibular motion in the sample studied were: maximum mandibular opening, $44.51 \mathrm{~mm}$; right lateral excursion, $7.71 \mathrm{~mm}$; left lateral excursion, $7.92 \mathrm{~mm}$, and protrusion $7.45 \mathrm{~mm}$;

- There was no difference between genders;

- The maximum mandibular opening and protrusion measures gradually increased with increasing age range. The right laterality measure followed the same tendency but a difference was demonstrated when the 6-8 and 10-12 year age ranges were compared.

On the basis of these findings, we may suggest that the mean and standard deviation of mandibular movement range should be considered according to age range in the evaluation of the stomatognathic system of children. 


\section{Anexo}

Protocol for multi-professional centers for the determination of signs and symptoms of temporomandibular disorders

Name:

PART I. Frequency of signs and symptoms of TMD

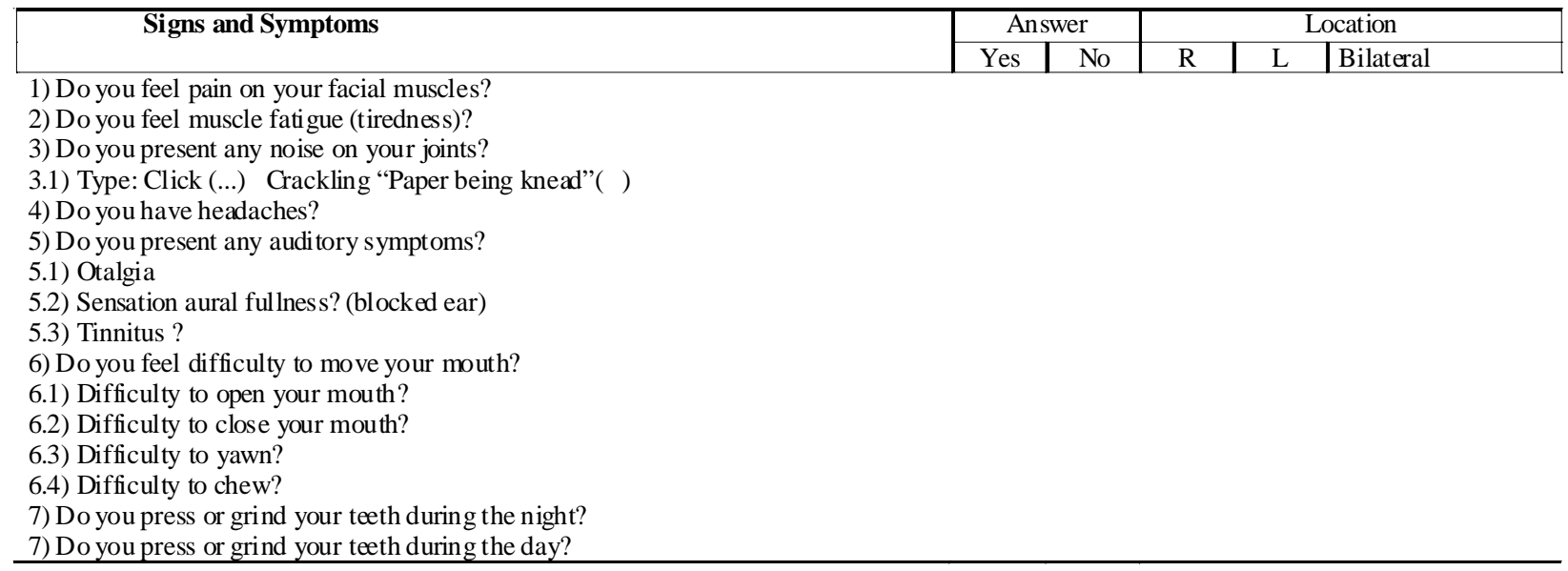

PART II. Severity of signs and symptoms of TMD. Instructions: please observe what your symptoms feel like in different situations and point to their severity, scoring from zero to ten. The more severe (strong and frequent) the symptom, the higher the score should be; the less severe, the lower the number. ZERO $(0)=$ no symptom TEN $(10)=$ the worse sensation

\begin{tabular}{|c|c|c|c|c|c|c|c|c|c|c|c|}
\hline \multicolumn{12}{|l|}{ When you wake up } \\
\hline 1) Pain on Facial Muscles & 0 & 1 & 2 & 3 & 4 & 5 & 6 & 7 & 8 & 9 & 10 \\
\hline 2) Pain on Articulation (TMJ) & 0 & 1 & 2 & 3 & 4 & 5 & 6 & 7 & 8 & 9 & 10 \\
\hline 3) Pain on the Neck & 0 & 1 & 2 & 3 & 4 & 5 & 6 & 7 & 8 & 9 & 10 \\
\hline 4) Earache & 0 & 1 & 2 & 3 & 4 & 5 & 6 & 7 & 8 & 9 & 10 \\
\hline 5) Tinnitus (buzzing) & 0 & 1 & 2 & 3 & 4 & 5 & 6 & 7 & 8 & 9 & 10 \\
\hline 6) Blocked Ears & 0 & 1 & 2 & 3 & 4 & 5 & 6 & 7 & 8 & 9 & 10 \\
\hline 7) Tooth Sensitiveness & 0 & 1 & 2 & 3 & 4 & 5 & 6 & 7 & 8 & 9 & 10 \\
\hline 8) Noise of articulation & 0 & 1 & 2 & 3 & 4 & 5 & 6 & 7 & 8 & 9 & 10 \\
\hline 9) Difficulty to chew & 0 & 1 & 2 & 3 & 4 & 5 & 6 & 7 & 8 & 9 & 10 \\
\hline
\end{tabular}

In the sequences, the same questions were repeated for the situations WHILE CHEWING, WHILE SPEAKING and WHILE RESTING (when resting, without neither speaking nor chewing). Source: Felício et al (21) 


\section{References}

1. Leles CR, Moreira Neto JJS, Giro EM, Compagnoni MA. Valores normais da amplitude do movimento mandibular em crianças. Rev Fac Odontol São José dos Campos. 2000;3(2):121-6.

2. Dworkin SF, Huggins KH, Leresche L, Von Korff M, Howard J, Truelove E, et al. Epidemiology of signs and symptoms in temporomandibular disorders: clinical signs in cases and controls. J Am Dent Assoc. 1990;120(3):27381

3. Vanderas AP. Mandibular movements and their relationship to age and body height in children with or without clinical signs of craniomandibular dysfunction: Part IV. A comparative study. ASDC J Dent Child. $1992 ; 59(5): 338-41$.

4. Celic R, Jerolimov V, Knezovic Zlataric D. Relationship of slightly limited mandibular movements to temporomandibular disorders. Braz Dent J. 2004;15(2):1514.

5. Bianchini EMG, Paiva G, Andrade CRF. Mandibular movements in speech: interference of temporomandibular dysfunction according to pain indexes. Pró Fono. 2007;19(1):7-18.

6. Sousa LM, Nagamine HM, Chaves TC, Grossi DB, Regalo $\mathrm{SCH}$, Oliveira AS. Evaluation of mandibular range of motion in Brazilian children and its correlation to age, height, weight, and gender. Braz Oral Res. 2008;22(1):61-6.

7. Duffy JP. Motor speech disorders: substrates, differential diagnosis e management. St. Louis: Mosby; 1995.

8. Agerberg G. Maximal mandibular movements in children. Acta Odont Scand. 1974;32(3):147-59.

9. Rothenberg LH. An analysis of maximum mandibular movements, craniofacial relationships and temporomandibular joint awareness in children. Angle Orthod. 1991;61(2):103-12.

10. Hirsch C, John MT, Lautenschlager C, List T. Mandibular jaw movement capacity in 10-17-year old children and adolescents: normative values and the influence of gender, age, and temporomandibular disorders. Eur. J. Oral Scie. 2006;114(6):465-70.

11. Hamazaki CM, Kawaura R, Bianchini EMG, AssencioFerreira VJ. Verificação da amplitude dos movimentos mandibulares em crianças. Rev. Cefac. 2002;4(1):35-40.

12. Ettala-Ylitalo UM, Lane T. Functional disturbances of the masticatory system in relation to articulatory disorders of speech in a group of 6-8-year-old children. Archs Oral Biol. 1991;36(3):189-94

13. Laine MT, Pahkala RH, Jaroma SM, Qvarnstrom. Associations among different orofacial dysfunctions in 68 year old. Arch. Oral. Biol. 1992;37(11):895-9.

14. Dijkstra PU, Hof AL, Stegenga B, Bonti LG. Influence of mandibular length on mouth opening. J. Oral Rehabil. 1999;26(2):117-22.

15. Lewis RP, Buschang PH, Throckmorton GS. Sex differences in mandibular movements during opening and closing. Am. J. Orthod. Dentofacial Orthop. 2001;120(3):294-303.
16. Fukui T, Tsuruta M, Murata K, Wakimoto Y, Tokiwa $\mathrm{H}$, Kuwahara Y. Correlation between facial morphology, mouth opening ability, and condylar movement during opening-closing jaw movements in female adults with normal occlusion. Eur J Orthod. 2002;24(4):327-36.

17. Pahkala RH, Qvarnstrom MJ. Mandibular movements capacity in 19-year-olds with and without articulatory speech disorders. Acta Odontol Scand. 2002;60(6):341-5.

18. Moipolai P, Karic VV, Miller VJ. The effect of the gonial angle, ramus length, age and gender on the temporomandibular opening index. J. Oral Rehabil. 2003;30(12):1195-9.

19. Gallagher C, Gallagher V, Whelton H, Cronin M. The normal range of mouth opening in an Irish population. $\mathrm{J}$. Oral Rehabil. 2004;31(2):110-6.

20. Farella M, Iodice G, Michelotti A, Leonardir R. The relationship between vertical craniofacial morphology and the sagittal path of mandibular movements. J. Oral Rehabil. 2005;32(12):857-62.

21. Felício CM, Mazzetto MO, Rodrigues da Silva MAM, Bataglion C, Hotta THA. Preliminary protocol for multiprofessional centers for determination of signs and symptoms of temporomandibular disorders. Crânio. 2006;24(4):258-64.

22. Felício CM, Melchior MO, Rodrigues da Silva MAM. Clinical validity of the protocol for multi-professional centers for the determination of signs and symptoms of temporomandibular disorders. Part II. Crânio. 2009;27(1):62-7.

23. Felício CM. Desordens Temporomandibulares (DTM): diagnóstico fonoaudiológico e terapia. In: Felicio CM. Fonoaudiologia aplicada a casos odontológicos: motricidade oral e audiologia. São Paulo: Pancast; 2001. p. 91-125.

24. Bonjardim LR, Gavião MBD, Pereira LJ, Castelo PM Mandibular movements in children with and without signs and symptoms of temporomandibular disorders. J. Appl. Oral Sci. 2004;12(1):39-44.

25. Farkas LG, Posnick JC, Hreczko TM. Growth patterns of the face: a morphometric study. Cleft Palate Craniofac. J. 1992;29(4):308-15.

26. Hayasaki H, Yamasaki Y, Nishima N, Naruse K, Nakata M. Characteristics of protrusive and lateral excursions of the mandible in children with the primary dentition. J. Oral Rehabil. 1998;25(4):311-20.

27. Kiliaridis S, Karlsson S, Kjellberg H. Characteristics of masticatory mandibular movements and velocity in growing individuals and young adults. J Dent Res. 1991;70(10):136770 .

28. Papargyriou G, Kjellberg H, Kiliaridis S. Changes in masticatory mandibular movements in growing individuals: a six-year follow-up. Acta Odontol Scand. 2000;58(3):12934.

29. Walsh B, Smith A. Articulatory movements in adolescents: Evidence for protracted development of speech motor control processes. J. Speech Lang. Hear Res. 2002;45(6):1119-33.

30. Cheng HY, Murdoch BE, Goozée JV, Scott D. Physiologic development of tongue-jaw coordination from childhood to adulthood. J. Speech Lang. Hear Res. 2007;50(2):352-60. 